\title{
A MODEL FOR MEASURING PASSENGER LOYALTY
}

\author{
Ilona Skačkauskienè ${ }^{1}$, Neringa Vilkaitè-Vaitonè ${ }^{2}$, \\ Jurgita Raudeliūnienè ${ }^{3}$, Vida Davidavičienè $\dot{e}^{4}$ \\ ${ }^{1,2}$ Dept of Social Economics and Management, Vilnius Gediminas Technical University, Lithuania \\ ${ }^{3,4}$ Dept of Business Technologies, Vilnius Gediminas Technical University, Lithuania
}

Submitted 9 April 2015; resubmitted 27 May 2015; accepted 1 June 2015;

first published online 9 October 2015

\begin{abstract}
Loyalty development is an essential condition for an increase in profit of airline, railway and road transport companies. It is undoubtedly relevant to the success of an organisation. However, there is a lack of unified and universally accepted indicators for customer loyalty. Consequently, a model for measuring customer loyalty can be barely applied to companies that provide transport services for passengers. This gap has presupposed the need to create a customer loyalty model that corresponds to modern needs of passenger transport organisations. The model needs to be flexible to be used by various transport organisations that provide services to passengers. Principal solutions for the design of a model for loyalty measurement emerged from the clarified role of passenger loyalty and evaluation problems. The worked out solutions include a selection of a proper concept (1), loyalty specification (2), and differentiation of loyalty measurement depending on accessible data (3). To measure loyalty, an informative and practical concept of loyalty has been chosen. Subsequently, a complex of indicators that correspond with features of passenger transport services was compiled and the measurement of customer loyalty was differentiated according to the situations of data accessibility. A quantitative model of passenger loyalty measurement is based on a behavioural concept and miscellaneous content. Therefore, it creates presumptions about measuring the state of passenger loyalty and choosing proper solutions for the development of passenger loyalty in transport organisations.
\end{abstract}

Keywords: passenger; passenger transport; loyalty; service loyalty; purchase value; purchase frequency.

\section{Introduction}

Delivery of a high-quality service to passengers is the core competitive advantage that determines the profitability and sustainable development of a passenger transport organisation (Al-Refaie et al. 2013, 2014). However, it is insufficient in the modern environment of intense competition, privatisation and deregulation of the passenger transport industry, liberalisation of railways, and replacement of traditional airlines with low-cost carriers. Today's world faces alterations in passenger demand and expectations. As for the transport industry, many passenger service providers have lost track of true needs of their passengers and are sticking to the outdated views regarding passenger transport service. The goal of a passenger service provider is to develop the package of services that attracts passengers and keeps them satisfied and loyal, sending information about the positive experience to others (Al-Refaie et al. 2014). Therefore, increasing passenger loyalty is a major factor in the ability of a passenger transport organisation to gener- ate profits. This statement can be substantiated by a significant growth in research efforts related to passenger loyalty in airline (Han et al. 2014; Chang, Hung 2013; Namukasa 2013; Al-Refaie et al. 2013, 2014), railway (Dölarslan 2014) and public transport (Lai, Chen 2011; Shiftan et al. 2015) companies.

Universally accepted indicators for customer loyalty do not exist despite many research efforts. It is also hard to find a model for customer loyalty measurement, which could be applied to companies providing passenger transport services. None of the models for customer loyalty measurement answers the current challenges and requirements faced by passenger transport businesses. Besides, the available models cannot be directly used for this purpose. The gap between the practical needs of transport service organisations and the methodological potential requires solving a rather complex problem of customer loyalty measurement. This complexity arises from difficulties in formally describing human psychological traits. The conducted investigations deal with a

Corresponding author: Ilona Skačkauskienè

E-mail: ilona.skackauskiene@vgtu.lt 
serious problem of measuring customer loyalty while answering to the question what constitutes the basis of the scientific problem; i.e. how to measure passenger loyalty? The situation encountered in the sector of passenger transport (intense competition, growing liberalisation, privatisation, etc.), the role of passenger transport in the national economy and the deficiency of the available methodological basis for loyalty measurement necessitate the development of an innovative approach to assessing the customer loyalty among passengers.

The object of this study is the measurement of passenger loyalty. With reference to the previous research by the authors of this paper (Skačkauskienè, VilkaitèVaitone 2014), it is treated as a positive attitude of passengers toward passenger transport service. In other word, the position that enhances the preference of a certain type of passenger transport services offered by a particular provider.

This research aims to create a model for passenger loyalty measurement. The model should correspond to modern needs of passenger transport organisations and should be flexibly used in various passenger transport organisations.

The methods of research include the analysis of scientific literature, comparative analysis, generalisation and mathematical modelling.

\section{Importance of Passenger Loyalty}

Customer loyalty is important for transport companies striving for survival and strengthening their competitiveness. First loyalty programmes were launched in 1981. One of them introduced a frequent-flyer programme developed by 'American Airlines. The company created the frequent flier program 'AAdvantage' that sought to reward loyal passengers through utilizing the excess capacity of airlines (Berman 2006). Later, similar programmes spread among road, rail and water transport companies.

There are several reasons why customer loyalty plays a crucial role in ensuring a competitive advantage of a passenger transport service provider. First, it is three to ten times less expensive for a business to retain its existing customers than to acquire new ones (Roy 2011; AlRefaie et al. 2013, 2014; Pratminingsih et al. 2013). The costs of acquiring new customers do not seem to be the only motive for stimulating passenger loyalty. Transport companies are interested in retaining passengers as their loyalty creates prerequisites for the generation of added value, increased market share and sales, and the development of the organisation toward the improvement of its business image (Bagdoniené, Jakštaite 2007; Terblanche, Boshoff 2010). A successful long-term relationship is an essential precondition for loyalty and brings benefits for reducing risk and uncertainty experienced by the customer (Bagdoniené, Jakštaite 2007). According to research made by Vavra (1992), a 50\% reduction in lost customers increases the profit of the organisation by $75 \%$. Results of the study conducted by Agustin and Singh (2005) are even more impressive: a 5\% change in loyalty can yield changes in profitability amounting from
25 to $100 \%$. Creation of long-term relationships between a passenger transport organisation and its customers is a far more profitable process than the attraction of new customers. Therefore, the development of passenger loyalty becomes an important aim of organisations operating in the industry of passenger transport.

Since goods and services have distinct characteristics, customer loyalty in the passenger transport industry is exceptional and obtains a certainly different form from the goods market. Javalgi and Moberg (1997) have provided some insight into this issue. The authors found that among customers who are familiar with one service, brand switching is less likely due to difficulties in measuring the quality of services, especially before the start of the use of new service. Besides, we have to consider the inseparability of a transport service provider and a passenger. Consequently, passengers may be less likely to switch after they develop a relationship with the provider. In addition, passenger transport services are intangible and heterogeneous. Therefore, most passengers perceive higher risk in service settings than in goods. As perceived risk increases, the likelihood of loyalty to one brand strengthens. The intangibility of services makes the measurement of service quality and satisfaction more difficult compared to goods. However, quality and satisfaction are relevant drivers of passenger loyalty. Besides, intangibility creates difficulties in gathering information about passenger transport services. Consequently, information about passenger transport services becomes more expensive. All these reasons seem to make customer loyalty more important for services than for goods (Javalgi, Moberg 1997).

Rowley and Daves (1999) considered the concept of customer loyalty in the commercial context. They found that managers focused their attention on possibilities to develop the loyalty of current customers, attract loyal customers and select a proper strategy for the management of customer loyalty. Omar (1999) found that a service organisation was incapable of gaining a competitive advantage and ensuring success without loyal customers. However, service loyalty can be managed only when measured. Rowley and Dawes (1999) acknowledge that an endeavour to measure customer loyalty reveals an innovative aspect of the nature of loyalty. Debates on selecting the means, methods and models of customer loyalty measurement started more than thirty years ago. Jacoby and Kyner (1973) were the first to deal with the problem. Nowadays, this issue has become an important object of research on loyalty in theory and practice, as knowledge of passenger loyalty leads to proper reaction to intense competition, market saturation and passenger migration.

Loyalty measurement is a prerequisite for developing customer loyalty in the passenger transport industry. It is essential to find a proper and reliable tool for measuring passenger loyalty since the measurement sorts out the most profitable passengers. The classification of passengers depending on their profitability leads to the differentiation of marketing campaigns, strategies and sales promotions. Such differentiation is based on 
passenger profitability and increases the effectiveness of the marketing programme. However, passenger loyalty measurement is a complex process that features many problems.

\section{Problems of Passenger Loyalty Measurement}

From 1990s, interest in the concept of loyalty and its benefits has increased though the process of measuring it is still limited and faces many problems.

The performed researches feature a variety of attitudes toward the measurement of customer loyalty. Although scientists mention plenty of methods for measuring customer loyalty, the majority of them are suitable only for certain cases and situations. The current methodological package is too scarce and not sufficiently developed for its practical use in the regime dictated by the business (Terblanche, Boshoff 2010; Worthington et al. 2010). Thus, despite an active interest in the concept of loyalty, progress in research on methods and means measuring customer loyalty is rather limited in terms of methodological validity and practical applicability.

The main impediment of customer loyalty measurement in passenger transport services is unclear conditions for treatment of the concept of loyalty. All methods measuring customer loyalty toward a service provider can be classified into behavioural, attitudinal and multidimensional (Chacon, Mason 2011; Roy 2011). The researchers' position regarding the concept of proper loyalty still lacks conformity. The position is based on different concepts and slightly varies or even contradicts in terms of results: a customer estimated to be loyal in one survey becomes a switcher in the other. This limits possibilities of comparing the results of separate studies. Practitioners are also uncertain about which concept of measuring passenger loyalty is the most superior.

Impartial measurement of passenger loyalty is also limited by the non-unified content of loyalty. This is indicated by a vast variety of loyalty measures, including the cycle of repurchase, the intensity of purchase, a period of use, a period of customer membership in the loyalty programme, the number of customers, net profit, etc. Until now, there has been still unclear which passenger loyalty elements should be measured in order to assess analogical passenger loyalty under identical or at least similar circumstances.

The insufficient differentiation of customer loyalty measurement according to data accessibility situations is an additional problem of measuring customer loyalty toward a service provider. A study conducted in 2012 by Columbia Business School and the New York Marketing Association found that $91 \%$ of marketing managers believed that to be successful organisations need to base marketing decisions on quantitative data (Aksoy 2013). This overwhelming desire is hard to implement in the passenger transport industry because information about passengers is rarely gathered, and the collected data are not always useful. Possible sources of data include passenger database, the e-ticket database, passenger surveys or external data. Scientists distinguish some loyalty measurement methods. However, limited data accessibility makes them suitable for use only in certain cases and in specific situations (Al-Awadi 2002; Bennett, Rundle-Thiele 2002). Such methods lack versatility in terms of their practical applicability in the transport sector. Consequently, if a passenger transport organisation does not collect data required for the practical application of the method for measuring passenger loyalty, the application of the selected technique becomes very limited. This problem could be solved by formulating loyalty measurement options in different data accessibility situations.

The identified problematic aspects of assessing customer loyalty undoubtedly encumber the measurement of passenger loyalty as well as highlight the insufficiency of the current methodological potential for the needs of modern-day practices in transport business. Its fragmentary nature has presupposed prioritising the creation of the model essentially based on new principles. The chosen proper solutions to substantiating the measurement of passenger loyalty cover the selection of a proper concept (1), the specification of loyalty (2) and the differentiation of loyalty measurement regarding accessible data (3).

\section{Model for Measuring Passenger Loyalty}

Two main streams in passenger loyalty - behavioural and attitudinal - can be distinguished. The measurements of attitudinal loyalty lack validity and practicality considering the aspect of costs; the provided information is insufficient for forecasting loyalty (Opperman 2000; Worthington et al. 2010). Therefore, it is not surprising that the dimension of behavioural loyalty initiated in the 1940s has become more common in research practice (Casaló et al. 2007; Tuu, Olsen 2010). The popularity of this dimension has been determined not only by the weaknesses of attitudinal loyalty but also by the influence of behavioural loyalty on the income and profit of an organisation (Bell, Eisingerich 2007; Chao 2008; Wong, Chung 2008). Considerations of behavioural loyalty, as an important outcome of relationships or as a measure of the efficiency of relationship marketing, also contribute to the popularity of behavioural loyalty dimension (Reinartz et al. 2008). In addition, behavioural loyalty matches the particularities of services (Setó-Pamies 2012). It is sufficiently informative, objective and reasonable regarding the aspect of available data (Khan 2009; Uncles et al. 2010; Worthington et al. 2010; Kabiraj, Shanmugan 2011). Despite the superiority of behavioural loyalty over attitudinal loyalty, loyalty measurement is not and cannot be isolated from the customer's attitude. Behavioural loyalty indirectly integrates attitudinal loyalty since loyal behaviour is impossible without a customer-friendly attitude toward the organisation and its services (Casaló et al. 2008; Leingpibul et al. 2009; Biscaia et al. 2013). After the formation of appropriate intentions and their active mode, attitudinal loyalty turns into behavioural loyalty (Kabiraj, Shanmugan 2011; Shiftan et al. 2015) or otherwise turns into the result of attitudinal loyalty. These arguments leave no 
doubt on the issue of selecting the concept of passenger loyalty; unambiguously - behavioural loyalty together with the influence of attitudinal loyalty, which becomes evident during the formation of loyalty.

In behavioural loyalty, various measures are used for service loyalty, including the cycle of repurchase, the intensity of purchase, a period of use, a period of customer membership in the loyalty programme, the number of customers, net profit, etc. However, the frequency (Meyer-Waarden 2008; Wong, Chung 2008; Carlson, O'Cass 2012; Shiftan et al. 2015) and the value of purchase (Matzler et al. 2007; Nadiri et al. 2008; Liu, Yang 2009) or both (Bodet, Bernache-Assollant 2011; Liu et al. 2012; Biscaia et al. 2013) are usually seen as the most favourable indicators for measuring behavioural loyalty. The measurement of passenger loyalty can be based on one of the measures mentioned above or both measures can be used.

The imperative of repetitive behaviour is seen as a feature of loyalty (Bee, Havitz 2010). Therefore, measuring passenger loyalty must integrate the frequency of purchase. According to Uncles et al. (2010), this measure serves as an indicator for service performance; the authors also emphasise its critical link to repeat purchase and long-term profitability. According to De Wulf et al. (2003), the frequency of purchase is accepted as the number of purchase a customer made at the company within a specified period. Meyer-Waarden (2008) states that an increase in the frequency of purchase is related to a declining number of the offers of competitors. Since passengers lack the information needed for comparison, they naturally become less price-sensitive. The intense frequency of purchase indicates the ability of a transport service provider to create high switching costs as well as a strong and frequently personal communication between the service provider and the passenger. Regarding the inseparability of services, a more frequent use of service determines a more active involvement of a passenger and increased participation in the process of service provision (Bell, Eisingerich 2007; Hosseini, M. H., Hosseini, V. S. 2013). This means that the higher the frequency of purchase is, the stronger relationship between the passenger and the service provider exists. Therefore, the passenger naturally becomes less price-sensitive.

Another measure of loyalty, i.e. the value of purchase, is integrated into the measurement of passenger loyalty since it shows the amount of passenger funds allocated for the provider of passenger transport services. According to Bee and Havitz (2010), the value of purchase is viewed as the main indicator of loyalty. Purchase value covers all costs for a certain passenger transport service. It is believed that loyal customers are less pricesensitive when compared to disloyal ones (Rafiq, Fulford 2005), as they are ready to spend more money on purpose to continue to liaise with an acceptable service provider. This is because the search for another service provider is associated with additional costs. Thus, there exists a higher probability that the value of the purchase of loyal passengers will be higher when compared with the value of disloyal passengers. The research carried out by Knox and Denison (2000) also confirms this proposi- tion: loyal customers tend to spend double the amount when compared to switchers.

Passenger loyalty can be measured through one of the indicators mentioned above or their combination. Convenience, sales promotions or the lack of choice determine inert purchase of passenger transport services. Consequently, the frequency of purchase is an insufficient measure for measurement of behavioural loyalty. Moreover, the measurement based solely on the value of purchase may show a false estimate of loyalty, i.e. highvalue purchase are probable, but can be occasional and without recurrence in the future. Since loyal behaviour is not casual (Casaló et al. 2007), the value of purchase is also insufficient for the measurement of passenger loyalty. A joint analysis of indicators for loyalty, i.e. the value and the frequency of purchase, is significant as both indicators reveal two different aspects essential for measuring passenger loyalty: the number of purchase cases and financial resources allocated to the provider of a passenger transport service. Therefore, it is suggested to measure passenger loyalty through the combination of indicators for the frequency and the value of purchase. These indicators are not only most frequently used measures of behavioural loyalty; they are also the ones that are most frequently registered in databases of passenger transport service providers, e-ticket databases and business management systems (Reinartz et al. 2008; Trépanier et al. 2012). Moreover, according to Bodet, Bernache-Assollant (2011), Quoquab et al. (2014), the combination of the frequency and the value of purchase is well suited for any service, including passenger transport. The above-mentioned arguments allow to treat the concept of passenger loyalty as the construct of behavioural loyalty that covers indicators for the frequency and value of purchase. It is suggested to define passenger loyalty by using the model presented in Eq. (1):

$$
L_{i j k}=f\left(v_{i j k}, d_{i j k}\right) \text {, }
$$

where: $L$ is loyalty; $v$ is the value of purchase; $d$ is the frequency of purchase; $i$ is a passenger $(i=1,2, \ldots, m)$; $j$ is a type of a passenger transport service $(j=1,2, \ldots$, $n) ; k$ is a provider of a passenger transport service $(k=$ $1,2, \ldots, p)$.

Given a variety of passengers in accordance with the extent and pattern of their consumption of passenger transport services, it is purposeful to base the measurement of loyalty on ratios, i.e. the value and frequency of the purchase shall be transformed into ratios. This is made through the application of normalisation procedures presented in Eqs (2) and (3):

$$
\begin{aligned}
& v_{i j k}=\frac{V_{i j k}}{\sum_{k} V_{i j k}} ; \\
& d_{i j k}=\frac{D_{i j k}}{\sum_{k} D_{i j k}},
\end{aligned}
$$

where: $V_{i j k}$ is the value of the purchase of the $i$-th passenger of the $j$-th type of the passenger transport service from the $k$-th provider of the passenger transport service 
(absolute value); $D_{i j k}$ is the frequency of the purchase of the $i$-th passenger of the $j$-th type of the passenger transport service from the $k$-th provider of the passenger transport service (absolute value).

Loyalty will be measured in regard to a particular type of the passenger transport service provided by a particular service organisation in accordance with the behaviour of passengers during a particular period $t$, which means that the array of data necessary for measuring loyalty must include figures on the value and frequency of purchase of every passenger. This data must show information about the purchase of a particular type of the passenger transport service from the analysed service provider $v_{i j k}$ and $d_{i j k}$, and the purchase from other suppliers of the same passenger transport service. Possible situations of data availability lead to three different options of passenger loyalty measurement (Fig.).

Option I provides a possibility of obtaining all data. The application of option 1 requires data on the frequency and values of purchase from the analysed provider and other suppliers of the same passenger transport services during a particular period $t$. It means that passenger loyalty is separately measured for every service. Thus, the following data are required:

- the number of passengers $i$ using a particular passenger transport service $j$ provided by the organisation;

- the number of other organisations $k$ providing a particular type of the passenger transport service $j$;

- the frequency of purchase of a particular type of the passenger transport service $j$ provided by the analysed organisation $D_{i j k}$;

- the value of purchase of a particular type of the passenger transport service $j$ provided by the analysed organisation $V_{i j k}$;

- the frequency of purchase of a particular type of the passenger transport service $j$ provided by all service providers $k-\left(\sum_{k} D_{i j k}\right)$;

- the value of purchase of a particular type of the passenger transport service $j$ provided by all service providers $k-\left(\sum_{k} V_{i j k}\right)$.
The following options on gaining all data are considered: consumption data (provided by the passenger) or business data (provided by the passenger transport company). With reference to data on the frequency of the purchase and values of the investigated passenger transport organisation as well as of other similar passenger service providers, the relative value and the frequency of purchase are calculated by Eqs (4) and (5). The values of the introduced indexes approximating to 1 show that a passenger is strongly linked to using services $j$ of the $k$-th service provider and is not interested in any other options. Such an alternative of passenger loyalty measurement causes the least trouble taking into account financial and time cost aspects.

Option II refers to the situation when only the data on the frequency of purchase and values of the investigated passenger transport organisation are known. Service organisations tend to register data on the frequency and value of purchase in databases (O'Malley 1998). However, accessibility to information about the frequency and value of passenger purchase in other organisations that provide the same services of passenger transport can be limited. When accessibility to such data is insufficient, slightly increased financial resources for measuring passenger loyalty must be allocated. $v_{i j k}$ and $d_{i j k}$ must be measured through the application of heuristic algorithms in accordance with $v_{j k}, v_{i k}, v_{i j k}, d_{j k}, d_{i k}, d_{i j k}$. For this purpose, marketing research must be carried out or data available in the organisation will be applied (through the application of the principle of analogy). For receiving data on the frequency and values of passenger purchase made by other organisations providing certain services, the principle of analogy is applied and covers: the results of other empirical research (1), the values and frequency of other service provided by the passenger transport organisation or other provider offering the $j$-th type of the passenger transport organisation service (2).

An alternative for obtaining the lacking data from other providers of the same passenger transport services exists. In such a case, information about the frequencies and the values of purchase should be transformed depending on sales by Eqs (6) and (7):

$$
d_{i j}=d_{i j k} \frac{P_{i j}}{P_{i j k}}
$$

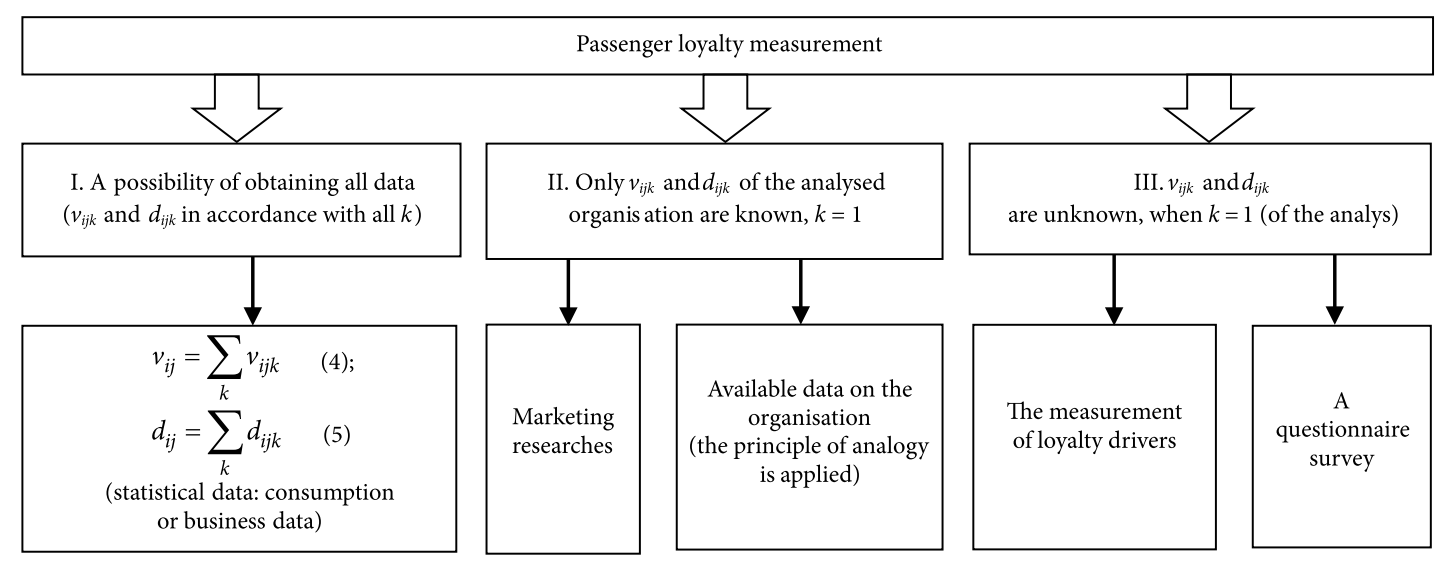

Fig. Options of passenger loyalty measurement 


$$
v_{i j}=v_{i j k} \frac{P_{i j}}{P_{i j k}},
$$

where: $P$ is the volume of sales.

Marketing research is another method used for obtaining the required data. Since information on the frequency and value of purchase is strictly numerical, only quantitative marketing studies will be applied.

Option III suggests that if data on the frequency and value of the purchase of the analysed organisation are unknown, loyalty drivers should be identified and measured. Passenger loyalty is determined by a wide spectrum of drivers. The problems arise when the exact set of drivers determining passenger loyalty is unknown. Such a set should include drivers for passengers, transport organisations and the environment. They must be systematised, and, therefore, scales have to be applicable in order to measure each driver. In case of the shortage of data necessary for measuring the loyalty of drivers, a survey necessary for collecting information has to be conducted. Various survey methods are applicable in order to measure the probable passenger loyalty: a questionnaire survey, interview, expert survey etc. All types of surveys have shortcomings limiting their applicability when measuring passenger loyalty. The questionnaire survey is the least disadvantageous of all survey methods and provides possibly the widest possibilities of loyalty application. In practice, it is treated as a convenient way to collect the required information.

The proposed model for measuring the customer loyalty of passenger transport services agrees with features of passenger transport services. The model measures loyalty for the passenger transport service and its elements. Another distinction of the innovative model is its applicability for every company providing passenger transport services. The practical use of the passenger loyalty model leads to sorting out the most profitable customers of the passenger transport organisation and to the differentiation of the marketing programme regarding the levels of passenger profitability.

The previous research made in the catering industry (Vilkaitè-Vaitonè 2014) disclosed the suitability and validity of the model for practical use. The results of the previous research revealed that every option of the model can assure validity and reliability because relative score mean error was significantly lower than $10 \%$ with $95 \%$ of fiducial probability. The appraisal of the model in the transport industry, where the competition between transport companies is intense, has not been surveyed yet. The suitability and efficiency of the model in the passenger transport industry, especially in different transport modes, is the object of the future research planned by the authors of this paper.

\section{Conclusions}

Aiming to reduce customer retention costs, increase sales and profits, a passenger transport organisation should pay a greater attention to passenger loyalty. Efficient management of passenger loyalty requires to consider its measurement. However, the measurement encounters numerous problems, e.g. a controversy over the concept and its elements or the lack of differentiation of customer loyalty measurement according to data accessibility situations. Traditional measurement models fail to address these problems due to methodological shortcomings. Consequently, the need arises to design an innovative model of measuring passenger loyalty.

The principal idea of the new approach to measuring passenger loyalty is to base it upon behavioural loyalty (together with the influence of attitudinal loyalty that becomes evident during loyalty formation). Two favourable indicators (purchase values and frequencies) are taken into account. The designed model has solved passenger loyalty problems common in science and practice and is suitable for use in different situations concerning data accessibility.

The use of a model for measuring passenger loyalty allows to evaluate passenger loyalty objectively and express it in a single value. A model is regarded suitable based on three different scenarios of data accessibility: possibility to obtain all data on the frequencies and values of purchase (1), unlimited accessibility only for data on frequencies and values of purchase in the analysed passenger transport organisation (2), inexistence of data on frequencies and values of purchase (3). Option 1 is based on business or consumption data and is the most superior in terms of accuracy, reliability, validity and the size of costs (financial, time and human resources). The realised principle of the adaptation for accessible data ensures the employment of the model in the environment of intense changes in the transport industry.

The developed original mathematical model has the potential to rationalise the marketing decisions in a passenger transport company. The model for loyalty measurement presented in this paper is not limited to the field of passenger transport, and thus can be adapted and widely applied in other segments of the transport industry.

\section{References}

Agustin, C.; Singh, J. 2005. Curvilinear effects of consumer loyalty determinants in relational exchanges, Journal of Marketing Research 42(1): 96-108. http://dx.doi.org/10.1509/jmkr.42.1.96.56961

Aksoy, L. 2013. How do you measure what you can't define?: The current state of loyalty measurement and management, Journal of Service Management 24(4): 356-381. http://dx.doi.org/10.1108/JOSM-01-2013-0018

Al-Awadi, A. 2002. A proposed model of consumer loyalty in the retailing sector based on the Kuwaiti experience, Total Quality Management 13(7): 1035-1046. http://dx.doi.org/10.1080/0954412022000017102

Al-Refaie, A.; Bata, N.; Eteiwi, D.; Jalham, I. 2014. Examining factors that affect passenger's overall satisfaction and loyalty: evidence from Jordan airport, Jordan Journal of Mechanical and Industrial Engineering 8(2): 94-101.

Al-Refaie, A.; Fouad, R. H.; Eteiwi, D. 2013. Examining factors affect passenger's satisfaction and loyalty: a compara- 
tive analysis from Jordan airport, Advances in Information Sciences and Service Sciences: an International Journal of Research and Innovation 5(3): 641-650.

http://dx.doi.org/10.4156/aiss.vol5.issue3.75

Bagdonienè, L.; Jakštaitè, R. 2007. Estimation of loyalty programmes from customers' point of view: cases of three retail store chains, Inžinerinè ekonomika - Engineering Economics (5): 51-58.

Bee, C. C.; Havitz, M. E. 2010. Exploring the relationship between involvement, fan attraction, psychological commitment and behavioural loyalty in a sports spectator context, International Journal of Sports Marketing \& Sponsorship 11(2): 140-157.

Bell, S. J.; Eisingerich, A. B. 2007. The paradox of customer education: customer expertise and loyalty in the financial services industry, European Journal of Marketing 41(5/6): 466-486. http://dx.doi.org/10.1108/03090560710737561

Bennett, R.; Rundle-Thiele, S. 2002. A comparison of attitudinal loyalty measurement approaches, Journal of Brand Management 9(3): 193-209.

http://dx.doi.org/10.1057/palgrave.bm.2540069

Berman, B. 2006. Developing an effective customer loyalty program, California Management Review 49(1): 123-148. http://dx.doi.org/10.2307/41166374

Biscaia, R.; Correia, A.; Rosado, A. F.; Ross, S. D.; Maroco, J. 2013. Sport sponsorship: the relationship between team loyalty, sponsorship awareness, attitude toward the sponsor and purchase intentions, Journal of Sport Management 27(4): 288-302.

Bodet, G.; Bernache-Assollant, I. 2011. Consumer loyalty in sport spectatorship services: the relationships with consumer satisfaction and team identification, Psychology \& Marketing 28(8): 781-802.

http://dx.doi.org/10.1002/mar.20412

Carlson, J.; O'Cass, A. 2012. Optimizing the online channel in professional sport to create trusting and loyal consumers: the role of the professional sports team brand and service quality, Journal of Sport Management 26(6): 463-478.

Casaló, L. V.; Flavián, C.; Guinalíu, M. 2008. The role of satisfaction and website usability in developing customer loyalty and positive word-of-mouth in the e-banking services, International Journal of Bank Marketing 26(6): 399-417. http://dx.doi.org/10.1108/02652320810902433

Casaló, L.; Flavián, C.; Guinalíu, M. 2007. The impact of participation in virtual brand communities on consumer trust and loyalty: the case of free software, Online Information Review 31(6): 775-792.

http://dx.doi.org/10.1108/14684520710841766

Chacon, J.; Mason, K. J. 2011. An analysis of the relationship between passenger loyalty and consumer buying behavior for network and low-cost carriers, Transportation Journal 50(3): 271-290.

http://dx.doi.org/10.5325/transportationj.50.3.0271

Chang, L.-Y.; Hung, S.-C. 2013. Adoption and loyalty toward low cost carriers: the case of Taipei-Singapore passengers, Transportation Research Part E: Logistics and Transportation Review 50: 29-36.

http://dx.doi.org/10.1016/j.tre.2012.10.003

Chao, P. 2008. Exploring the nature of the relationships between service quality and customer loyalty: an attributelevel analysis, The Service Industries Journal 28(1): 95-116. http://dx.doi.org/10.1080/02642060701725610

De Wulf, K.; Odekerken-Schröder, G.; De Canniére, M. H.; Van Oppen, C. 2003. What drives consumer participation to loyalty programs? A conjoint analytical approach, Journal of Relationship Marketing 2(1-2): 69-83.

http://dx.doi.org/10.1300/J366v02n01_05

Dölarslan, E. S. 2014. Assessing the effects of satisfaction and value on customer loyalty behaviors in service environments: high-speed railway in Turkey as a case study, Management Research Review 37(8): 706-727.

http://dx.doi.org/10.1108/MRR-06-2013-0152

Han, H.; Hyun, S. S.; Kim, W. 2014. In-flight service performance and passenger loyalty: a cross-national (China/Korea) study of travelers using low-cost carriers, Journal of Travel \& Tourism Marketing 31(5): 589-609.

http://dx.doi.org/10.1080/10548408.2014.883954

Hosseini, M. H.; Hosseini, V. S. 2013. The impact of co-production on customer loyalty in banking services: a case of Saman bank, Iranian Journal of Management Studies 6(2): 105-129.

Jacoby, J.; Kyner, D. B. 1973. Brand loyalty vs. repeat purchasing behaviour, Journal of Marketing Research 10(1): 1-9. http://dx.doi.org/10.2307/3149402

Javalgi, R. R. G.; Moberg, C. R. 1997. Service loyalty: implications for service providers, Journal of Services Marketing 11(3): 165-179. http://dx.doi.org/10.1108/08876049710168663

Kabiraj, S.; Shanmugan, J. 2011. Development of a conceptual framework for brand loyalty: a Euro-Mediterranean perspective, Journal of Brand Management 18(4-5): 285-299. http://dx.doi.org/10.1057/bm.2010.42

Khan, B. M. 2009. Consumers and their brands: deciphering dimensions of loyalty, International Journal of Business Insights and Transformation 2(1): 84-92.

Knox, S. D.; Denison, T. J. 2000. Store loyalty: its impact on retail revenue. An empirical study of purchasing behaviour in the UK, Journal of Retailing and Consumer Services 7(1): 33-45. http://dx.doi.org/10.1016/S0969-6989(98)00033-2

Lai, W.-T.; Chen, C.-F. 2011. Behavioral intentions of public transit passengers: the roles of service quality, perceived value, satisfaction and involvement, Transport Policy 18(2): 318-325. http://dx.doi.org/10.1016/j.tranpol.2010.09.003

Leingpibul, T.; Thomas, S.; Broyles, S. A.; Ross, R. H. 2009. Loyalty's influence on the consumer satisfaction and (re) purchase behavior relationship, Journal of Consumer Satisfaction, Dissatisfaction \& Complaining Behavior 22: 36-53.

Liu, M. T.; Brock, J. L.; Singh, R.; Chu, R.; Sy-Changco, J. 2012. What drives Indian consumer credit card loyalty? The perspective of involvement in reward programmes, The International Review of Retail, Distribution and Consumer Research 22(4): 365-383. http://dx.doi.org/10.1080/09593969.2012.690776

Liu, Y.; Yang, R. 2009. Competing loyalty programs: impact of market saturation, market share, and category expandability, Journal of Marketing 73(1): 93-108. http://dx.doi.org/10.1509/jmkg.73.1.93

Matzler, K.; Füller, J.; Faullant, R. 2007. Customer satisfaction and loyalty to Alpine ski resorts: the moderating effect of lifestyle, spending and customers' skiing skills, International Journal of Tourism Research 9(6): 409-421. http://dx.doi.org/10.1002/jtr.613

Meyer-Waarden, L. 2008. The influence of loyalty programme membership on customer purchase behaviour, European Journal of Marketing 42(1-2): 87-114. http://dx.doi.org/10.1108/03090560810840925

Nadiri, H.; Hussain, K.; Ekiz, E. H.; Erdoğan, S. 2008. An investigation on the factors influencing passengers' loyalty in 
the North Cyprus national airline, The TQM Journal 20(3): 265-280. http://dx.doi.org/10.1108/17542730810867272

Namukasa, J. 2013. The influence of airline service quality on passenger satisfaction and loyalty: the case of Uganda airline industry, The TQM Journal 25(5): 520-532. http://dx.doi.org/10.1108/TQM-11-2012-0092

O’Malley, L. 1998. Can loyalty schemes really build loyalty?, Marketing Intelligence \& Planning 16(1): 47-55. http://dx.doi.org/10.1108/02634509810199535

Omar, O. 1999. Retail Marketing. 1st edition. Financial Times/ Prentice Hall. 464 p.

Opperman, M. 2000. Where psychology and geography interface in tourism research and theory, in A. G. Woodside, G. I. Crouch, J. A. Mazanec, M. Opperman, Y. Sakai (Eds.). Consumer Psychology of Tourism, Hospitality and Leisure, 19-37.

Pratminingsih, S. A.; Rudatin, C. L.; Suhardi, A. R. 2013. Retaining passengers loyalty in Indonesia railway service, in 4th International Conference on Business and Economic Research (4th ICBER 2013), 4-5 March 2013, Bandung, Indonesia, 611-619.

Quoquab, F.; Yasin, N. M.; Dardak, R. A. 2014. A qualitative inquiry of multi-brand loyalty: some propositions and implications for mobile phone service providers, Asia Pacific Journal of Marketing and Logistics 26(2): 250-271. http://dx.doi.org/10.1108/APJML-02-2013-0023

Rafiq, M.; Fulford, H. 2005. Loyalty transfer from offline to online stores in the UK grocery industry, International Journal of Retail \& Distribution Management 33(6): 444-460. http://dx.doi.org/10.1108/09590550510600861

Reinartz, W.; Thomas, J. S.; Bascoul, G. 2008. Investigating cross-buying and customer loyalty, Journal of Interactive Marketing 22(1): 5-20. http://dx.doi.org/10.1002/dir.20106

Rowley, J.; Dawes, J. 1999. Customer loyalty - a relevant concept for libraries?, Library Management 20(6): 345-351. http://dx.doi.org/10.1108/01435129910280474

Roy, S. 2011. Brand loyalty measurement: a framework, SCMS Journal of Indian Management 8(2): 112-122.

Setó-Pamies, D. 2012. Customer loyalty to service providers: examining the role of service quality, customer satisfaction and trust, Total Quality Management \& Business Excellence 23(11-12): 1257-1271. http://dx.doi.org/10.1080/14783363.2012.669551

Shiftan, Y.; Barlach, Y.; Shefer, D. 2015. Measuring passenger loyalty to public transport modes, Journal of Public Transportation 18(1): 1-16. http://dx.doi.org/10.5038/2375-0901.18.1.7

Skačkauskienė, I.; Vilkaitè-Vaitonė, N. 2014. Measurement of customer loyalty towards service providers: a conceptual framework, International Journal of Management - Theory and Applications 2(4): 109-115.

Terblanche, N. S.; Boshoff, C. 2010. Quality, value, satisfaction and loyalty amongst race groups: a study of customers in the South African fast food industry, South African Journal of Business Management 41(1): 1-9.

Trépanier, M.; Habib, K. M. N.; Morency, C. 2012. Are transit users loyal? Revelations from a hazard model based on smart card data, Canadian Journal of Civil Engineering 39(6): 610-618. http://dx.doi.org/10.1139/12012-048

Tuu, H. H.; Olsen, S. O. 2010. Nonlinear effects between satisfaction and loyalty: an empirical study of different conceptual relationships, Journal of Targeting, Measurement and Analysis for Marketing 18(3-4): 239-251.

http://dx.doi.org/10.1057/jt.2010.19
Uncles, M. D.; Wang, C.; Kwok, S. 2010. A temporal analysis of behavioural brand loyalty among urban Chinese consumers, Journal of Marketing Management 26(9-10): 921-942. http://dx.doi.org/10.1080/02672570903441454

Vavra, T. G. 1992. Aftermarketing: How to Keep Customers for Life through Relationship Marketing. Irwin Professional Pub. 300 p.

Vilkaité-Vaitonè, N. 2014. Paslaugu vartotojų lojalumo vertinimas: daktaro disertacija. Vilnius: Technika. 172 p. (in Lithuanian).

Wong, J.-Y.; Chung, P.-H. 2008. Retaining passenger loyalty through data mining: a case study of Taiwanese airlines, Transportation Journal 47(1): 17-29.

Worthington, S.; Russell-Bennett, R.; Härtel, C. 2010. A tridimensional approach for auditing brand loyalty, Journal of Brand Management 17(4): 243-253. http://dx.doi.org/10.1057/bm.2009.24 